UDC [37.016:51]:81'246.2 (=161.1=512.157)

DOI: $10.23951 / 2782-2575-2021-1-75-86$

\title{
PEDAGOGICAL CONDITIONS FOR FORMING BILINGUAL MATHEMATICAL COMPETENCE IN BASIC SCHOOL STUDENTS*
}

\section{N.I. Spiridonova}

\section{Federal Institute of Native Languages of the Peoples of the Russian Federation, Yakutsk}

Introduction. In the process of bilingual education, schoolchildren must not only qualitatively master the content of the subject but also overcome language difficulties. There is a connection between speech and mathematical activities. The essence and structure of bilingual mathematical competence are based on this relationship, allowing bilingual students to effectively acquire knowledge in the conditions of national-Russian bilingualism. We have also proposed ways of forming bilingual mathematical competence focused on developing mathematical speech culture and teaching schoolchildren to use multicultural knowledge.

Aim. The article aims to characterize the pedagogical conditions directed at the emergence of bilingual mathematical competence among basic school students (grades 5 to 9) within national-Russian bilingualism.

Material and methods. The study relies on theoretical methods of comparative analysis, synthesis, and generalization provided by the scientific and methodological literature on the researched topic.

Results and discussion. Works indicating a clear relationship between the language of instruction and the subject of Mathematics were analyzed. The need to take into account the mother tongue of schoolchildren in bilingual education was established. In addition, it was found that the degree of native and Russian language proficiency affects the mathematics achievement of bilingual students. According to the analysis, bilingual education should lead to the emergence of competencies distinguished by a high level of language proficiency and high-quality mastering of the subject.

Conclusion. The concept of "bilingual mathematical competence" got a detailed description in the course of the research. This concept combines components of a school subject, languages ( native and Russian), and a component of intercultural communication. The following pedagogical components were described:

1) tasks aimed at mastering terminology, symbols, and graphic images; verbal and logical constructions of the mathematical language; written educational texts;

2) illustrated Yakut-Russian, Russian-Yakut terminological dictionary in mathematics for the $5^{\text {th }}$ and $6^{\text {th }}$ grades, which includes 349 terms and set phrases;

3) bilingual strategies aimed at reducing the linguistic complexity of mathematical problems (by replacing unfamiliar or rare words; changing the passive voice to active verb forms; reducing long names and indications; highlighting individual conditional sentences, or changing the order of the conditional and main sentences; replacing complex questions to simple ones; clarification of abstractions using more specific information);

4) methods and techniques of bilingual teaching of mathematics (consecutive translation, visual aids, immersion teaching, semantization);

5) tasks that contain historical, ethnocultural, and local history materials.

\footnotetext{
* Original Russian language version of the article: Spiridonova N.I. Formirovaniye bilingval'oy matematicheskoy kompetentsii u obuchayuschikhsya osnovnoy shkoly v usloviyakh natsional'no-russkogo dvuyazychiya [Formation of Bilingual Mathematical Competence in Primary School Pupils in the Conditions of National Russian Bilingualism]. Vestnik Tomskogo gosudarstvennogo pedagogicheskogo universiteta - TSPU Bulletin, 2020, vol. 6 (212), pp. 27-38. DOI: 10.23951/1609-624X-2020-6-27-38 (in Russian).
} 
Keywords: bilingual mathematical competence, instruction language, bilingualism, bilingual student, bitext, the culture of mathematical speech, bilingual student.

\section{Introduction}

Recently, the development of bilingual education has become a growing trend all over the world. Various options of its implementation are used: 1) based on the languages spoken by a linguistic majority/minority; 2) based on the official language of the state, as well as the languages of ethnic groups; 3) based on the native and foreign languages [1, p. 91]. Citizens of the Russian Federation have the right to get preschool, primary and basic education both in their native language and in Russian [2]. Russia is a multinational state, and there are 277 languages and dialects, 30 of which are used as the language of instruction [3]. The Republic of Sakha (Yakutia) has officially adopted the second state language - the Yakut language (Sakha) [4], which, along with Russian, is the language of instruction. In Yakutia, from 1917 to the present, the following models of bilingual education have been formed: the "Linguistic Heritage" program, a transitional model, and immersion education [5]. According to the experience of basic education organizations that implement the native (Sakha) language of instruction in primary grades, bilingualism (the process of alternating use of languages [6, p. 22]) is formed with an emphasis on the native language of students. In the $5^{\text {th }}$ and $6^{\text {th }}$ grades of the middle school, there is a gradual transition from the native language to Russian; in the $7^{\text {th }}$ to $11^{\text {th }}$ grades, on the contrary, bilingualism with an emphasis on the Russian language is observed.

In the context of the Russian national bilingualism, in which the first component of bilingualism is the native language, and the second is Russian [7], a study of Mathematics is often associated with mathematical and linguistic difficulties. According to M. K. Cirillo, R. Bruna, B. Herbel-Eisenmann [8], and P. Ron [9], it would be a mistake to believe that even students with a high level of language proficiency can automatically master the oral and written forms of mathematical speech. It is evident that in national schools, language difficulties may be more pronounced when teaching mathematics. We believe that the poor level of Russian language proficiency and the flow of thought processes mainly in their native language can cause these difficulties.

Since studying mathematics, like any other academic discipline, is impossible without mathematical and natural languages $[10,11]$, the relationship between speech and mathematical activity should be considered in educational practice. Thus, this article clarifies the concept and structure of bilingual mathematical competence, which allows students to successfully master the primary school curriculum in the conditions of national-Russian bilingualism; Presented below are ways of forming such competence.

\section{Materials and methods}

Within the framework of this study, domestic and foreign scientific and methodological literature was analyzed. The synthesis and generalization of the data obtained during the analysis made it possible to reveal the meaning of the concept "bilingual mathematical competence" and describe the forms, resources, and methods of its formation in the conditions of national-Russian bilingualism.

Let us consider the relationship between the language of instruction and mathematical content. The results of many foreign studies show that the mathematical and language skills of students are closely interrelated [12]. Several studies indicate that language skills [13], reading comprehension [14], and vocabulary [15] can be identified as significant predictors of the development of math skills. K. Bochnik and S. Ufer [16] proved that subject-specific language 
skills partially mediate the relationship between general language and math skills. In their study, S. Prediger and L. Wessel noted the significant role of subject-specific language registers necessary for understanding the meaning of mathematical concepts [17]. By "register," we mean a functional variety of a language in various situational contexts (a text consisting of lexical and grammatical units typical for a particular communicational situation) [18]. According to M.A.K. Halliday, the term "mathematical register" denotes language expression for mathematical purposes, where natural languages play a significant role in the expression of mathematical ideas. Just like other natural languages, a mathematical language has some specific features [19]. It is known that a mathematical language is used to describe representations, examples, or phenomena associated with previously studied mathematical concepts. It includes the vocabulary specific to the subject and more complex skills such as the derivation of mathematical structures described verbally [20].

Let us highlight some studies that have identified the differences between casual and academic language registers [21]. S. Prediger and L. Wessel believe that mathematical concepts within classroom discourse are described according to a specific register [17]. The school language register, which is part of the academic language register [22], is located between the informal register and the technical register, which describes language in teaching mathematics as a school subject [17]. Members of the National Council of Teachers of Mathematics also believe that there is a "more mathematically structured" language between casual and academic languages [23]. Let's consider that the actual mathematical language is an extension of the natural language [24], then the use of the casual spoken language can be viewed as the basis for developing the mathematical language.

Many scientists believe that academic achievements are associated with general language competence and text comprehension [25-29]. The reasons for this underlie the educational and linguistic requirements of the subject "Mathematics" (for example, reading and understanding the texts on mathematical problems) [30]. Since the language carries two functions (communicative, cognitive), it is difficult for learners to overcome the language requirements in the oral and written environment when teaching mathematics $[31,32]$. It is evident that the conditions of nationalRussian bilingualism exacerbate this problem. According to L. Wessel, the use of the native language in multilingual classes (especially at the initial stage) is crucial for forming and using an abstract mathematical language in speech [33]. Many studies on multilingualism in the educational environment show how important it is to take into account the native language of students when using a second language as the language of instruction [34]. Indeed, bilingual students who speak both languages at a sufficiently high level of proficiency show excellent results in math education [23, 35-39]. A smooth transition of instruction language from the native language to Russian helps schoolchildren overcome linguistic and subject difficulties in teaching mathematics [40].

Following L. T. Zembatova, we understand the concept of "bilingual teaching in mathematics" "as an interconnected activity of a teacher and a student, aimed at the formation of mathematical knowledge using the native and Russian languages resulting in the deep, conscious acquisition of mathematical content, the development of mathematical speech, the formation of a culture of mathematical thinking, as well as in increasing of proficiency level in a second language (Russian)" [41, p. 177].

The result of bilingual education is the synthesis of specific competencies, ensuring a high level of language proficiency and deep mastery of subject content [42, 43]. According to The Threshold Theory, a necessary condition for achieving a positive influence of bilingualism on the intellectual development of schoolchildren is the formation of bilingual competence. J. Cummins $[23,44]$ distinguishes two levels of bilingual competence: 1) "BICS" (Basic Interpersonal Communicative Skills) - basic language proficiency at the level of everyday communication; 
2) "CALP" (Cognitive Academic Language Proficiency) - the use of a second language at a higher level in the learning process.

To reveal the essence of the "bilingual mathematical competence" concept, let us analyze concepts that are close in meaning to it. A.V. Khutorskoy defines the concept of "competence" as a set of interrelated personal traits (knowledge, abilities, skills, methods of activity) related to a specific range of objects and processes which are necessary for achieving productive activity in interaction with these objects and processes [45].

N. Chomsky [46] defines the concept of "linguistic competence" as the ability to understand and reproduce an unlimited number of correct sentences through the acquired linguistic signs and the rules for their connection. He also believes that linguistic competence is perfect grammatical knowledge, which is always correlated with knowledge of a language system.

D.H. Hymes [47] expanded the concept of "language competence" and introduced the concept of "communicative competence," which denotes the sum of language skills and knowledge of the speaker/listener under changing situations and conditions of speech.

Yu.L. Semenova studied the formation of bilingual communicative competence of schoolchildren and defined it as "the ability (mastery of subject and language competences in two languages) and students' readiness (competence of personal self-improvement) to carry out effective interpersonal, intergroup and intercultural communication both in their native language and foreign language" [48, p. 69].

Some scientists $[45,49-51]$ believe that the concept of "subject competence" includes the abilities required to perform specific actions in any subject category and narrow-subject knowledge, skills, and abilities as well as methods of thinking. In particular, mathematical competence is the ability to structure data (a situation), isolate mathematical relations, create a mathematical model of a situation, analyze and transform it, and interpret the results obtained [52].

So, to define the concept of "bilingual mathematical competence," we will operate with such concepts as "knowledge," "skills," "ability," and "readiness" [53].

Abilities are individual psychological characteristics of a personality expressed in its activities that are conditional for the success of the activities. The overall mastery of knowledge, skills, and abilities (in terms of depth, easy-learning, high learning pace) depends on abilities, but they are not limited to knowledge and skills [54].

Readiness is also based on the activity approach and implies one's desire to do something. In pedagogy, "readiness" is used as an integrative concept and includes ideas about readiness for certain activity types, such as readiness for school teaching [55, p. 148].

Theoretical analysis of the literature showed that in modern pedagogy, despite extensive data on the competence-based approach in education, the problem concerning the formation of subject competence in the process of bilingual teaching of mathematics is not given due attention. Among the researches, we would like to note the works related to the formation of bilingual subject competence in mathematics for primary school students [56] and higher educational institutions [43]. Based on the definitions by L. L. Salekhova [43] and L.T. Zembatova [56], we define bilingual mathematical competence of primary school students as a didactic category denoting a set of intercultural and special mathematical knowledge, skills, and abilities that ensure the readiness to implement successful educational activities in the native and Russian languages in the conditions of national-Russian bilingualism. We also clarify its structural composition, which consists of the following components: subject (mathematics), special language (native language), special language (Russian), and intercultural component.

The mastery of the school curriculum in mathematics and the level of mathematical thinking among students is reflected in the subject component of bilingual mathematical competence. The 
subject component consists of knowledge system of the scientific conceptual mathematical apparatus (basic laws of mathematics, mathematical concepts), mathematical language (semantics and syntax), universal mathematical methods (mathematical description of processes, mathematical modeling), as well as skills and abilities of mathematization of empirical material (application of the concepts and methods of mathematics for the quantitative analysis of processes and phenomena of the world), the logical organization of mathematical material, and the application of mathematical theory (the ability to apply mathematical concepts, mathematical methods and mathematical language, extract mathematical information from educational texts, translate the information received into the language of mathematics, solve mathematical problems, perform computational actions, use computer technologies, evaluate mathematical objects and phenomena from the position of previously acquired knowledge, present mathematical objects in the form of diagrams, graphs, formulas).

The language components in the native and Russian languages consist of general language and speech competencies and include students' mathematical speech in their native and Russian languages. These components also characterize the degree of language proficiency of schoolchildren and their ability to use languages in speech. A sufficient level of language components allows students to use mathematical language based on their native and Russian languages, such as explaining the material covered, describing objects or conditions, introducing mathematical concepts, commenting on the problem-solving situations.

A sufficient formation level of the intercultural component allows bilingual schoolchildren to apply multicultural knowledge in bilingual education, allowing them to use more methods of mental activity, thereby deepening and consolidating the knowledge gained and also making it easier to participate in communication with members of a multicultural society.

\section{Results and discussion}

Let us describe the methodology for the formation of bilingual mathematical competence. In order to implement successful educational activities in the native and Russian languages, the following principles can be applied, taking into account the linguistic properties as a means of teaching [57]:

1. Integrated language and subject learning (using the native language of learners, observing and providing support to learners, understanding subject matter, and supporting learning processes through task-oriented language work).

2. There is speech attention and speech consciousness (specific and consciously developed speech action, awareness, and reflection of linguistic phenomena, terms, or structures).

3. Active actions and interaction of languages (stimulating students to participate in active speech activity).

4. Transparency of language requirements (clarification of language learning goals along with subject goals).

5. Systematic language support (teacher assistance only if necessary, when the student cannot cope with the task independently).

6. Emphasis on written speech (stimulating lengthy consistent oral and written texts).

7. Emphasis on working with text (providing a plan for writing and reading, operating with longer texts).

Applying these principles helps ease the language difficulties that bilingual children experience in the teaching of mathematics. In order to follow these principles, it is necessary to use bilingual teaching methods. Scientists have different opinions on the methods of bilingual education. Based on the works of A.G. Shirin [42], N. Masch [58], M.N. Pevzner [59], E. Turman 
[60], E.S. Pavlov [61], it is possible to distinguish a set of methods of bilingual education: 1) methods of teaching mathematics; 2) methods of teaching native and Russian languages; 3) general didactic methods: traditional (frontal, teacher's report, standardized conversation, reproductive-response method); developing methods (work in group and pairs, discussion, debate, role play, panel discussion, brainstorming, problem-based learning); open methods (free activity, project activity, independent activity, individual educational project, information technology); 4) special methods and techniques: immersion methods (total and soft immersion); language support (visual support, reading support, language support); bilingual teaching techniques (input, bridging prompting, code-switching).

These teaching methods are also applicable for the formation of bilingual mathematical competence. In addition to textbooks, we suggest using a system of mathematical tasks aimed at developing mathematical speech in schoolchildren (as in the case of the Yakut-Russian bilingualism). The system forms the subject and special language components (native and Russian) of bilingual mathematical competence. Tasks are presented in parallel texts in the native (Yakut) and Russian languages, i.e., texts in one language and their translation into another language [62]. The task system consists of the following components:

1. Tasks designed for working with terminology, symbols, and graphical images:

- explanation of terms, symbols, and symbolic expressions, the origin of terms; correlation of terms with each other; explanation of the symbols meaning and symbolic expressions;

- transition from a graphical form of notation to a verbal-symbolic form ("reading" of graphical images);

- transition from a symbolic (verbal) form of notation to a graphical presentation;

- writing mathematical sentences (or individual terms) using symbols;

- reading symbols;

- transformation of symbols;

- terminological vocabulary test;

- consecutive translation.

2. Tasks designed to work with the verbal and logical constructions of the mathematical language:

- finding false or missing features in the definitions of mathematical concepts;

- finding errors in the definitions of mathematical concepts;

- true or false statements;

- students' independent wording of mathematical sentences.

3. Tasks designed to work with written training texts:

- finding unknown words, language phrases, and symbols in the text;

- finding errors in the text;

- making a coherent text from "scattered" sentences (or fragments);

- filling in gaps in the text.

4. Tasks designed for working with text tasks (commenting on solving a text problem).

For example, let us consider tasks requiring students to explain the meaning of terms and symbolic expressions.

Table 1

Math problems in the native language (Sakha) and the Russian language requiring an explanation of the term

1 холобур. «Сөптөөх доруоп» тиэрмин суолтатын $\quad$ Example 1. Объясни значение термина «правильная тылгынан быһаaр (быһааран суруй). дробь». (Explain the meaning of the term «correct fraction») 
The answer in the native language of the students can be as follows: «Знаменателэ числителинээ丂эр улахан көннөру доруоп сөптөөх доруоп буолар. Холобур, знаменателгэ турар 2 чыыһыла числителгэ турар 1 чыыһылатаађар улахан буолан, икки гыммыт биирэ доруоп сөптөөх доруоп буолар. $2>1,1 / 2$ - сөптөөх доруоп».

The answer in Russian can be as follows: «Правильная дробь - это обыкновенная дробь, в которой числитель меньше знаменателя. Например, дробь одна вторая является правильной дробью, так как в числителе стоит натуральное число 1, которое меньше числа 2, стоящего в знаменателе дроби. правильная дробь, так как $1<2$ ». (A regular fraction is an ordinary fraction in which the numerator is less than the denominator. For example, a one-half fraction is a regular fraction, since the numerator contains a natural number 1 , which is less than the number 2 in the denominator of the fraction. It is a regular fraction since $1<2$ )

Table 2

Parallel text translations of a math problem in the native (Sakha) and Russian languages, requiring an explanation of the meaning of symbolic expressions

\begin{tabular}{|c|c|}
\hline $\begin{array}{c}2 \text { холобур. Бэриллибитхолобурдар- } \\
\text { тансөптөөх холобуру бул: } \\
\begin{aligned} \text { a) НОД }(4 ; 18)=18 \\
\text { b) }\left|-3 \frac{1}{4}\right|<1 \frac{1}{2} \\
\text { c) } 34 \cdot(-7)=-238 . \text { Эппиэккин } \\
\text { быhaаp }\end{aligned}\end{array}$ & $\begin{array}{c}\text { Example 2. } \\
\text { Какие из символических записей } \\
\text { правильные? Объясни свой ответ: } \\
\text { a) НОД }(4 ; 18)=18 ; \\
\text { b) }\left|-3 \frac{1}{4}\right|<1 \frac{1}{2} ; \\
\text { c) } 34(-7)=-238 \\
\text { (Which of the symbolic notations are } \\
\text { correct? Explain your answer: } \\
\text { a) GCD }(4 ; 18)=18 ; \\
\text { b) }\left|-3 \frac{1}{4}\right|<1 \frac{1}{2} ; \\
\text { c) } 34(-7)=-238\end{array}$ \\
\hline
\end{tabular}

The answer in the student's native language: «Сөптөөх холобур ууруктаах уонна мэлдьэхтээх чыыһылалар төгүллээһиннэрэ буолар $(34 \cdot-7=-38$. Ууруктаах уонна мэлдьэхтээх чыыһылалары төгүлллүүргэ бу чыыһылалар муодулларын төгүллээн этиллии суолтатын булабыт. Ууруктаах уонна мэлдьэхтээх чыыһылалар үөскэмнэрэ мэлдьэхтээх чыыһыла буоларын иһин, тахсыбыт чыыһыла иннигэр «-» бэлиэни туруорабыт. НОД $(4 ; 18)=18$ холобур суолтата суох буолар. 4 чыыһыла 18 чыыһылақа түнэтиллибэт буолан, 4 уонна 18 чыыһылалар саамай улахан уопсай түнэтээччилэрэ 18-ка тэннэспэт. Ханнык бақарар чыыһыла муодула ууруктаах чыыһыла буолан, икки ууруктаах булкаас чыыһылалары тэнниибит. Бэриллэбит мэлдьэхтээх чыыһыла муодула ууруктаах чыыһылатаақар улахан буолан, тэнэ-суох сыыһа холобур буолар».

The answer in Russian: «Запись НОД $(4 ; 18)=18$ неверна, так как число 18 не является делителем числа 4, поэтому наибольший общий делитель чисел 4 и 18 не может быть равен 18. Также не имеет смысл запись, так как модуль отрицательного числа - $31 / 4$ равен 3 1/4. Сравнив два смешанных положительных числа, выясним, что 3 1/4 больше 1 1/2. Среди данных примеров правильным оказался пример, где предтавлена запись $34 \cdot(-7)=-238$, так как при умножении чисел с разными знаками модули этих чисел перемножаются, а перед произведением ставится знак «-». В результате умножения положительного числа 34 и отрицательного числа (-7) получаем отрицательное число (-238)» (Recording GCD $(4 ; 18)=18$ is incorrect, since the number 18 is not a divisor of the number 4 , therefore the greatest common divisor of the numbers 4 and 18 cannot be equal to 18 . It also makes no sense to write, since the modulus of a negative number is $-31 / 4$ is equal to $31 / 4$. Comparing the two 
mixed positive numbers, we find that $31 / 4$ is greater than $11 / 2$. Among these examples, the correct example turned out to be where the notation $34 \cdot(-7)=-238$ is presented, since when multiplying numbers with different signs, the moduli of these numbers are multiplied, and a "_" sign is placed in front of the product. As a result of multiplying a positive number 34 and a negative number $(-7)$, we get a negative number $(-238)$ ).

The answers of bilingual students must be accurate and proper, i.e., mathematical terms and expressions correctly should be written correctly (following the literary native and Russian languages), sentences must be formulated precisely, their explanation must be complete, notes must be made accurately. In addition, the reasoning of children must be logically structured so that they can come to the correct conclusion. In other words, the communicative qualities of mathematical speech among schoolchildren should be at a sufficiently high level. For example, a teacher can periodically monitor the development of the basic communicative qualities of mathematical speech (correctness, consistency, accuracy, relevance) [63], the level of formation of which shows the level of development of the culture of mathematical speech as a whole. Students should consciously switch from one language to another when providing an answer while not mixing them. A solution can also be presented orally.

Such tasks allow us to apply the above principles in Maths class and use the techniques and methods of bilingual learning to control the processes of switching and mixing language codes and avoid the negative consequences of language contacts and interferences.

It is necessary to offer students word problems containing the following materials to form an intercultural component in Maths lessons: historical (historical events, biographies of mathematicians), ethnocultural (traditions, culture, national values, experience-based knowledge of peoples), as well as materials based on local history (geographical, cultural, historical, economic, ethnographic features of Russia and the republic).

In addition to the tasks system in Maths lessons, a dictionary can be used as an additional teaching aid, for example, a dictionary of mathematical terms [64], visual support cards, comparison tables, and Internet resources.

\section{Conclusion}

Since the study of mathematics is closely related to language processes, the interdependence between speech and mathematical activity should be taken into account in educational practice. In the conditions of national-Russian bilingualism in schools, bilingual education should be focused on developing competencies in schoolchildren, ensuring the achievement of a high proficiency level of mathematical speech in two languages, and the ability to communicate with members of a multicultural society. That is, the result of bilingual teaching in mathematics should be considered the formation of bilingual mathematical competence.

\section{References}

1. Kachalov N.A., Polesyuk R.S. Bilingval'noye obrazovaniye kak sredstvo mezhkul'turnoy podgotovki uchitelya inostrannogo yazyka [Bilingual education as a means of intercultural training of a foreign language teacher]. Vestnik Tomskogo gosudarstvennogo pedagogicheskogo universiteta (Seriya: Gumanitarnye nauki (filologiya) TSPU Bulletin, 2006, no. 9 (60), pp. 90-93 (in Russian).

2. Federal'nyy zakon "Ob obrazovanii v Rossiyskoy Federatsii" ot 29.12.2012 no. 273-FZ (red. ot 26.07.2019) [Federal law "About education in the Russian Federation" from 29 December 2012 no. 273-FZ (as amended 26 July 2019)]. http://www.consultant.ru/document/cons_doc_LAW_140174/bf7fadb3532c712ccd28cc2599243 $\mathrm{fb} 8018 \mathrm{ed} 869 /$ (in Russian).

3. Ukaz Prezidenta RF ot 19.12.2012 no. 1666 "O strategii gosudarstvennoy natsional'noy politiki Rossiyskoy Federatsii na period do 2025 goda" (red. ot 06.12.2018) [On the Strategy of the state national policy of the 
Russian Federation for the period up to 2025 (as revised on 6 December 2018)]. URL: http://www.consultant.ru/ document/cons_doc_LAW_139350/(in Russian).

4. Zakon Respubliki Sakha (Yakutiya) ot 16.10 .1992 no. 1170-XII "O yazykakh v Respublike Sakha (Yakutiya)" (s izmeneniyami na 30.05.2017) [Law of the Republic of Sakha (Yakutia) dated 16 October 1992 No. 1170-XII "On languages in the Republic of Sakha (Yakutia)" (as amended on: 30 May 2017) (in Russian). URL: http://docs.cntd. $\mathrm{ru} /$ document/804911252

5. Petrova A.I. Stanovleniye i razvitiye sistemy dvuyazychnogo obrazovaniya: istoriya, teoriya, opyt, perspektivy (na primere matematicheskogo obrazovaniya v Respublike Sakha (Yakutiya)) (na materialakh Yakutii XVIII-XX vv.) [Formation and development of the system of bilingual education: history, theory, experience, prospects (on the example of mathematical education in the Republic of Sakha (Yakutia)) (on the materials of Yakutia XVIIIXX centuries)]. Under the scientific editorship of G. L. Lukankin. Moscow, Izdatel'stvo MGOU Publ., 161 p. (in Russian).

6. Vaynraykh U. Odnoyazychiye i mnogoyazychiye [Monolingualism and multilingualism]. Novoye v lingvistike [New in linguistics]. Moscow, Progress Publ., 1972, pp. 25-60 (in Russian).

7. Zherebilo T.V. Terminy i ponyatiya lingvistiki: Obshcheye yazykoznaniye. Sotsiolingvistika: Slovar'-spravochnik (960 slovarnykh statey) [Terms and concepts of linguistics: General linguistics. Sociolinguistics: Dictionaryreference (960 dictionary articles)]. Narzan', Piligrim Publ., 2011. 280 p. (in Russian).

8. Cirillo M., Bruna K.R., Herbel-Eisenmann B. Acquisition of Mathematical Language: Suggestions and Activities for English Language Learners. Multicultural Perspectives, 2010, no. 12 (1), pp. 34-41. DOI: $10.1080 / 15210961003641385$

9. Ron P. Spanish-English Language Issues in the Mathematics Classroom. Changing the Faces of Mathematics: Perspectives on Latinos. Ed. by L. Ortiz-Franco, N.G. Hernandez, Y. de la Cruz. Reston, VA: National Council of Teacher of Mathematics, 1999. P. 23-34.

10. Kempert S., Saalbach H., Hardy I. Cognitive benefits and costs of bilingualism in elementary school students: The case of mathematical word problems. Journal of Educational Psychology, 2011, no. 103 (3), pp. 547-561. DOI: http://dx.doi.org/10.1037/a0023619

11. Abedi J., Lord C. The language factor in mathematics tests. Applied Measurement in Education, 2001, no. 14 (3), pp. 219-234. DOI: https://doi. org/10.1207/S15324818AME1403_2

12. Tarelli I., Schwippert K., Stubbe T.C. Mathematische und naturwissenschaftliche Kompetenzen von Schülerinnen und Schülern mit Migrationshintergrund. TIMSS 2011: Mathematische und naturwissenschaftliche Kompetenzen von Grundschulkindern in Deutschland im internationalen Vergleich. Eds. By W. Bos, H. Wendt, O. Köller, C. Selter. Münster: Waxmann, 2012. pp. 247-267.

13. Ufer S., Reiss K., Mehringer V. Sprachstand, soziale Herkunft und Bilingualität: Effekte auf Facetten mathematischer Kompetenz. Sprache im Fach. Eds. by M. Becker-Mrotzek, K. Schramm, E. Thürmann, H.J. Vollmer. Münster: Waxmann, 2013. S. 185-202.

14. Paetsch J., Radmann S., Felbrich A., Lehmann R., Stanat P. Sprachkompetenz als Prädiktor mathematischer Kompetenzentwicklung von Kindern deutscher und nicht-deutscher Familiensprache. Zeitschrift für Entwicklungspsychologie und Pädagogische Psychologie, 2016, no. 48, pp. 27-41.

15. Paetsch J., Felbrich A., Stanat P. Der Zusammenhang von sprachlichen und mathematischen Kompetenzen bei Kindern mit Deutsch als Zweitsprache. Zeitschrift für Pädagogische Psychologie, 2015, no. 29, pp. 19-29.

16. Bochnik K., Ufer S. Die Rolle (fach-)sprachlicher Kompetenzen zur Erklärung mathematischer Kompetenzunterschiede zwischen Kindern mit deutscher und nicht-deutscher Familiensprache. Zeitschrift für Grundschulforschung, 2016a, no. 9 (1), pp. 135-147.

17. Prediger S., Wessel L. Fostering German-language learners' constructions of meanings for fractions: design and effects of a language-and mathematics-integrated intervention. Mathematics Education Research Journal, 2013, no. 25 (3), pp. 435-456.

18. Halliday M.A.K., MacIntosh A. and Strevens P. The Linguistic Sciences and Language Teaching. London: Longman, 1964.

19. Halliday M.A.K. Language as Social Semiotic. London: Edward Arnold, 1978. P. 195.

20. Gabler L., Ufer S. Sprachliche Flexibilität von Grundvorstellungen zu Addition und Subtraktion - Eine Vorstudie zu einem Förderkonzept für die zweite Jahrgangsstufe. Journal für Mathematikdidaktik, under revision. (n.d.).

21. Cummins J. BICS and CALP: empirical and theoretical status of the distinction. In: Encyclopedia of language and education Berlin. Heidelberg: Springer, 2008. Pp. 487-499. 
22. Schleppegrell M.J. Linguistic features of the language of schooling. Linguistics and education, 2001, no. 12 (4), pp. 431-459.

23. Cummins J. Interdependence of first - and second - language proficiency in bilingual children. In: E. Bialystok (ed.) Language Processing in Bilingual children. Cambridge: Cambridge University Press, 1991. Pp. 70-89.

24. Dorofeyev G.V. O nekotorykh osobennostyakh real'nogo yazyka matematiki [About some features of the real language of mathematics]. Matematika v shkole, 1999, no. 6, pp. 4-12 (in Russian).

25. Duarte J., Gogolin I., Kaiser G. Sprachlich bedingte Schwierigkeiten von mehrsprachigen Schülerinnen und Schülern bei Textaufgaben. In: Mathematiklernen unter Bedingungen der Mehrsprachigkeit. Stand und Perspektive der Forschung und Entwicklung in Deutschland. Hrsg. E. Özdil, S. Prediger. Münster: Waxmann, 2011. S. 35-54.

26. Paetsch J., Felbrich A. Longitudinale Zusammenhänge zwischen sprachlichen Kompetenzen und elementaren mathematischen Modellierungskompetenzen bei Kindern mit Deutsch als Zweitsprache. Psychologie in Erziehung Und Unterricht, 2016, vol. 1, pp. 16-33. DOI: https://doi.org/10.2378/peu2016. art03d

27. Plath J., Leiss D. The impact of linguistic complexity on the solution of mathematical modelling tasks. Springer Science and Business Media LLC, 2018, vol. 50, pp. 159-171. DOI: https://doi.org/10.1007/s11858-017-0897-x

28. Prediger S., Krögeloh N. Low achieving eighth graders learn to crack word problems: a design research project for aligning a strategic scaffolding tool to students' mental processes. ZDM Mathematics Education, 2015, no. 47 (6), pp. $947-962$.

29. Vukovic R.K., Lesaux N. The language of mathematics: Investigating the ways language counts for children's mathematical development. Journal of Experimental Child Psychology, 2013, vol. 115 (2), pp. 227-244. DOI: https://doi.org/10.1016/j.jecp.2013.02.002

30. Leiss D., Schukajlow S., Blum W., Messner R., Pekrun R. Zur Rolle des Situationsmodells beim mathematischen Modellieren - Aufgabenanalysen, Schülerkompetenzen und Lehrerinterventionen. Journal für MathematikDidaktik, 2010, vol. 31, pp. 119-141. DOI: https://doi.org/10.1007/s13138-010-0006-y

31. Maier H., Schweiger F. Mathematik und Sprache: Zum Verstehen und Verwenden von Fachsprache im Mathematikunterricht. Wien, 1999.

32. Morek M., Heller V. Bildungssprache - Kommunikative, epistemische, soziale und interaktive Aspekte ihres Gebrauchs. Zentralblatt Für Didaktik Der Mathematik, 2012, no. 57 (1), pp. 67-101.

33. Wessel L. Fachund sprachintegrierte Förderung durch Darstellungsvernetzung und Scaffolding. Ein Entwicklungsforschungsprojekt zum Anteilbegriff. Heidelberg: Springer Spektrum, 2015.

34. Cummins J. The role of primary language development in promoting education success for language minority students. In: California State Department of Education (Eds.), Schooling and language minority students. A theoretical framework. Los Angeles: National Dissemination and Assessment Center, 1981. Pp. 3-49.

35. Clarkson P. C. Language and mathematics. A comparison of bilingual and monolingual students of mathematics. Educational Studies in Mathematics. Netherlands: Springer Netherlands, 1992, no. 23 (4), pp. 417-429.

36. Clarkson P.C., Dawe L. NESB migrant students studying Mathematics: Vietnamese students in Melbourne and Sydney. In: Pehkonen E. (ed.) Proceedings of the 21st Conference of the International Group for the Psychology of Mathematics Education. Lahte, Finland: International Group for the Psychology Mathematics Education, 1997, vol. 2, pp. 153-160.

37. Moschkovich J. A situated and sociocultural perspective on bilingual mathematics learners. In: Mathematical Thinking and Learning. Philadelphia, USA: Taylor \& Francis, Inc., 2002, no. 4 (2-3), pp. 189-212.

38. Secada W.C. Race, ethnicity, social class, language and achievement in mathematics. In: Handbook of Research on Mathematics Teaching and Learning. New York: MacMillan, 1992. Pp. 623-661.

39. Setati M. Researching mathematics education and language in multilingual South Africa. In: The Mathematics Educator. Athens, USA: Mathematics Education Student Association, 2002, no. 12 (2), pp. 6-20.

40. Zembatova L.T. Realizatsiya printsipa polilingval'nosti v protsesse izucheniya matematiki v natsional'noy shkole Implementation of the principle of polylinguality in the process of studying mathematics in the national school]. European Social Science Journal, 2011, no. 3, pp. 44-48 (in Russian).

41.Zembatova L.T. Povysheniye kachestva nachal'nogo obrazovaniya $v$ natsional'noy shkole na osnove polilingval'nogo i polikulturnogo podkhodov: na primere distsipliny "Matematika". Dis. dokt. ped. nauk [Improving the quality of primary education in the national school on the basis of polylingual and multicultural approaches: on the example of the discipline "Mathematics". Diss. of doct. of ped. sci.]. Vladikavkaz, 2014. 386 p. (in Russian). 
42. Siguan M. Obrazovanie i dvuyazychie [Education and bilingualism]. Moscow, Pedagogika, 1990. 181 p. (in Russian).

43. Shirin A. G. Bilingval'noye obrazovaniye v otechestvennoy i zarubezhnoy pedagogike. Avtoref. dis. d-ra ped. nauk [Bilingual education in domestic and foreign pedagogy. Abstract of thesis doct. of ped. sci.]. Velikiy Novgorod, 2007. 54 p. (in Russian).

44. Salekhova L.L. Model' i urovni realizatsii tekhnologii formirovaniya bilingval'noy predmetnoy kompetentsii budushchikh uchiteley [The model and the levels of realization of the technology of forming bilingual subject competence of future teachers]. Vestnik TGGPU - TSHPU Bulletin, 2010, no. 20 (in Russian). URL: https:// cyberleninka.ru/article/n/model-i-urovni-realizatsii-tehnologii-formirovaniya-bilingvalnoy-predmetnoykompetentsii-buduschih-uchiteley (accessed 28 April 2020).

45. Cummins J. Language. Power and Pedagogy Bilingual Children in the Crossfire. Clevedon, Multilingual Matters, 2000 .

46. Khutorskoy A.V. Klyuchevye kompetentsii i obrazovatel'nye standarty [Key competencies and educational standards]. Eydos, 2002, no. 2, pp. 58-64 (in Russian).

47. Chomsky N. Aspekty teorii sintaksisa: perevod s angliyskogo [Aspects of the theory of syntax: translated from English]. Edited, with a preface by V.A. Zvegintsev. Moscow, MSU Publ., 1972. 259 p. (in Russian).

48. Hymes D.H. Sociolinguistics. Selected Readings. Harmondsworth, Penguin Education Publ., 1972. P. 269-293.

49. Semenova Yu.L. Formirovaniye bilingval'noy kommunikativnoy kompetentsii uchashchikhsya gimnazii v usloviyakh dialoga kul'tur Formation of bilingual communicative competence of high school students in the context of a dialogue of cultures]. Vestnik Surgutskogo gosudarstvennogo pedagogicheskogo universiteta - The Surgut State Pedagogical University Bulletin, 2011, no. 3 (in Russian). URL: https://cyberleninka.ru/article/n/ formirovanie-bilingvalnoy-kommunikativnoy-kompetentsii-uchas-chihsya-gimnazii-v-usloviyah-dialoga-kultur (accessed 14 August 2020).

50. Zimnyaya I.A. Klyuchevye kompetentsii - novaya paradigma rezul'tata obrazovaniya [Key competencies - a new paradigm of educational results]. Vyssheye obrazovaniye segodnya, 2003, no. 5, pp. 34- 42 (in Russian).

51. Rodzhers K. Voprosy, kotorye ya by sebe zadal, esli by byl uchitelem [Questions I would ask myself if I were a teacher]. Eksperiment $i$ innovatsii v shkole, 2011, no. 4, pp. 10-13 (in Russian).

52. Shishov S.E., Kal'ney V.A. Shkola: monitoring kachestva obrazovaniya [School: monitoring the quality of education]. Moscow, Pedagogicheskoye obshchestvo Rossii Publ., 2000. 320 p. (in Russian).

53. Lun'kova T.M. Formirovaniye kompetentsiy na urokakh matematiki formation of competencies in mathematics lessons] (in Russian). URL: http://festival.1september.ru/articles/530530/ (accessed 24 April 2020).

54. Lobos E., Macura J. Mathematical competencies of engineering students // ICEE-2010, International Conference on Engineering Education. July 18-22, 2010, Gliwice, Poland. Silestian University of Technology.

55.Zeidmane A., Rubina T. Student-Related factor for dropping out in the first year of studies at LLU engineering programmes // Engineering for Rural Development. 2017. No. 16. Pp. 612-618. DOI: 10.22616/ERDev2017.16. N122

56. Steyn T., Plessis I.D. Competence in mathematics - more than mathematical skills? International Journal of Mathematical Education in Science and Technology, 2007, vol. 38, issue 7, pp. 881-890. DOI: 10.1080/00207390701579472

57.Zimnyaya I.A. Psikhologicheskiye aspekty obucheniya govoreniya na inostrannom yazyke [Psychological aspects of teaching speaking in a foreign language]. Moscow, Prosveshcheniye Publ., 1985. 160 p. (in Russian).

58. Kalashnikov M.M. K voprosu o sushchnosti ponyatiya sposobnostey v pedagogike i psikhologii [On the question of the essence of the concept of abilities in pedagogy and psychology]. Vestnik BGU-BSU Herald, 2014, no. 1 (in Russian). URL: https://cyberleninka.ru/article/n/k-voprosu-o-suschnosti-ponyatiya-sposobnostey-v-pedagogikei-psihologii (accessed 5 May 2020).

59. Evsyukova N.I. Psikhologo-pedagogicheskiye usloviya formirovaniya gotovnosti yunoshey doprizyvnogo vozrasta $k$ sluzhbe $v$ vooruzhennykh silakh [Psychological and pedagogical conditions of formation of readiness of young men of pre-conscription age for service in the armed forces]. Vladimir, Vyatka State University Publ., 2009. 192 p. (in Russian).

60. Zembatova L.T. Formirovaniye bilingval'noy (osetinsko-russkoy) matematicheskoy kompetentsii na nachal'nom etape obucheniya [Formation of bilingual (Ossetian-Russian) mathematical competence at the initial stage of training]. Vestnik GUU - Vestnik Universiteta, 2013, no. 21 (in Russian). URL: https://cyberleninka.ru/article/n/ 
formirovanie-bilingvalnoy-osetinsko-russkoy-matematicheskoy-kompetentsii-na-nachalnom-etape-obucheniya (accessed 28 May 2020).

61. Federal'nyj gosudarstvennyj obrazovatel'nyj standart osnovnogo obshchego obrazovaniya (utv. prikazom Ministerstva obrazovaniya i nauki RF ot 17 dekabrya $2010 \mathrm{~g}$. N 1897) [Federal state educational standard of basic education (approved by Order of the Ministry of Education and Science of the Russian Federation of December 17, 2010 N 1897)]. https://fgos.ru/(in Russian).

62. Muzhikova, A.V., Gabova, M.N. (2020). Development of Competent Mathematical Speech of Students at Technical University. Vysshee obrazovanie v Rossii - Higher Education in Russia. Vol. 29, no. 1, pp. 66-75. (In Russ., abstract in Eng.) DOI: https://doi.org/10.31992/0869-3617-2020-29-1-66-75

63. Nalimova I.V., Elifant'eva S.S. Razvitie matematicheskoj rechi v processe podgotovki budushchih uchitelej nachal'nyh klassov [The development of mathematical speech in the process of training future primary school teachers]. Yaroslavskij pedagogicheskij vestnik, 2018. no. 2, pp. 74-77 (in Russian).

64. Schmölzer-Eibinger S., Dorner M., Langer E., Helten-Pacher M. Sprachförderung im Fachunterucht in sprachlich heterogenen Klassen. Stuttgart, Klett Publ., 2013.

65. Andreev V.I. Pedagogika tvorcheskogo samorazvitiya [Pedagogy of creative self-development]. Kazan', 1996. P. 568 (in Russian).

66. Sharmin D.V. Formirovaniye kul'tury matematicheskoy rechi uchashchikhsya $v$ protsesse obucheniya algebre $i$ nachalam analiza. Dis. kand. ped. nauk Formation of the culture of mathematical speech of students in the process of teaching algebra and the basics of analysis. Diss. cand. ped. sci.]. Omsk, 2005. 212 p. (in Russian).

67. Spiridonova N.I., Savvinova A.D. (compilers) Yakutsko-russkiy, russko-yakutskiy terminologicheskiy slovar' po matematike dlya uchashchikhsya osnovnoy shkoly [Yakut-Russian, Russian-Yakut terminological dictionary of mathematics for primary school students.]. Yakutsk, Dani-Almas Publ., 2016. 88 p. (in Russian).

68. Egorov I. G., Petrov P. P., Petrova A. I. (compilers) Russko-yakutskij tolkovyj slovar' matematicheskih terminov [Russian-Yakut explanatory dictionary of mathematical terms]. Yakutsk, Bichik, 1998. P. 184 (in Russian).

69. Orfograficheskij slovar' yakutskogo yazyka [Spelling dictionary of the Yakut language]. Yakutsk, Bichik, 2015.P.479 (in Russian).

70. Nikolsky S.M., Potapov M.K. et al. Matematika. 5 klass. Uchebnik [Mathematics. Grade 5. Textbook]. Moscow, 2015. P. 272 (in Russian).

71. Wode H. Immersion: Mehrsprachigkeit durch mehrsprachigen Unterricht. Informationshefte zum Lernen in der Fremdsprache 1. Eichtatt, Kiel. 1990.

72. Turman E. Bilingualen Lernen. Wege zur Mehrsprachingkeit. Neue deutsche Scule, 1994, no. 46, pp. 34-36.

73. Pevzner M.N., Shirin A.G. Bilingval'noye obrazovaniye v kontekste mirovogo opyta (Na primere Germanii) [Bilingual education in the context of world experience (on the example of Germany)]. Novgorod, Yaroslav-theWise NovSU Publ., 1999. 96 p. (in Russian).

74. Salekhova L.L. Didakticheskaya model' bilingval'nogo obucheniya matematike v vysshej pedagogicheskoj shkole. Dis. dokt. ped. nauk [Didactic model of bilingual teaching of mathematics in the higher pedagogical school. Diss. doct. ped. sci]. Kazan', 2008. P. 447 (in Russian).

75. Pavlova E.S. Metodika bilingval'nogo obucheniya khimii uchashchikhsya osnovnoy shkoly. Dis. kand. ped. nauk [Methods of bilingual teaching of chemistry to primary school students. Diss. cand. ped. sci]. Saint Petersburg, 2011. 155 p. (in Russian).

76. Petrova A.I., Kajgorodov S.P., E.A. Il'ina, Spiridonova N.I., Terent'eva M.D. Narodnye matematicheskie zadachi kak sredstvo uchebno-poznavatel'noj deyatel'nosti [Folk mathematical problems as a means of educational and cognitive activity]. Kazanskaya nauka, 2012, no 11, pp. 288-293 (in Russian).

77. Petrova A.I., Gabysheva S.A., Tomskaj G.V., Kajgorodov S.P., Ushnickaj S.M., Kuz'mina L.M., Chenyanova N.I., Chekanceva N.I., Argunova N.V. Saha myndyr suota. Yakutsk, Bichik, 2012. P. 72 [in Yakut].

Nataliya I. Spiridonova, Senior Research Officer, Federal Institute of Native Languages of the Peoples of the Russian Federation in Yakutsk (pr. Lenina, 4/2, Yakutsk, Russian Federation, 677000). E-mail: tashachen@mail.ru 